\title{
Prinsip-Prinsip Kepemimpinan Penggembalaan \\ Berdasarkan Yohanes 10:1-21 dan \\ Implementasinya dalam Kepemimpinan Gereja
}

\section{Principles of Pastoral Leadership Based on John 10:1-21 and The Implementation in Church Leadership}

\author{
Hanny Frederik ${ }^{1)}$ \\ 1) Mahasiswa Program Studi Doktoral Teologi, Sekolah Tinggi Filsafat Theologia Jaffray Makassar \\ *Penulis Korespondensi: frederikhanny@gmail.com
}

Received: 1506 2020/ Accepted: 0211 2020/ Published: 01122020

\begin{abstract}
Abstrak
Kepemimpinan penggembalaan menghadapi banyak tantangan, terutama di dunia yang modern pada masa kini, baik dari dalam maupun dari luar gereja yang siap menghadang dan menggagalkan kepemimpinan seorang gembala jemaat. Karena itu, kepemimpinan penggembalaan harus menyadari perlunya menerapkan prinsip-prinsip tertentu dalam pelaksanaan tugas dan tanggung jawabnya. Prinsip-prinsip itu adalah prinsip-prinsip yang Alkitabiah atau bersumber dari firman Allah. Penelitian ini bertujuan menggali prinsip-prinsip kepemimpinan penggembalaan berdasarkan pengajaran Yesus dalam Injil Yohanes 10:1-21 dan implementasinya dalam kepemimpinan gereja. Penelitian ini adalah penelitian kualitatif yang bersifat penelitian kepustakaan dengan menggunakan metode hermeneutik Alkitab. Berdasarkan pengajaran Yesus dalam Yohanes 10:1-21, dapat ditarik beberapa prinsip kepemimpinan penggembalaan yang dapat diimplementasikan pada kepemimpinan gereja. Beberapa prinsip itu adalah prinsip panggilan Allah, pemeliharaan, berpusat pada Yesus Kristus, pengorbanan, kesetaraan, dan perluasan kerajaan Allah.

Kata-kata Kunci: Gembala, Kepemimpinan, Penggembalaan, Yohanes 10:1-21.
\end{abstract}

\begin{abstract}
Pastoral leadership faces many challenges, especially in today's modern world, both from within and from outside the church who are ready to confront and frustrate the leadership of a pastor. Therefore, shepherding leadership must recognize the need to apply certain principles in carrying out its duties and responsibilities. Those principles are biblical principles or derived from the word of God. This study aims to explore the principles of pastoral leadership based on Jesus' teachings in the Gospel of John 10: 1-21 and their implementation in church leadership. This research is qualitative in the form of library research using
\end{abstract}


the biblical hermeneutic method. Based on Jesus' teachings in John 10: 1-21, some shepherding leadership principles can be drawn that can be implemented in church leadership. Some of these principles are the principles of God's calling, providence, centering on Jesus Christ, sacrifice, equality, and expansion of the kingdom of God.

Keywords: Leadership, Pastoral, Shepherding, John 10:1-21.

\section{PENDAHULUAN}

Kepemimpinan merupakan topik yang akan terus dibahas selama masih ada kehidupan manusia di dunia ini. Kepemimpinan selalu dibutuhkan oleh manusia, baik dalam komunitas maupun dalam kehidupan seorang manusia secara pribadi. Tanpa kepemimpinan, maka kehidupan seseorang atau suatu komunitas atau organisasi akan mengalami kekacauan dan berjalan tanpa arah, karena tidak ada yang mengatur dan mengarahkan. Tanpa kepemimpinan, maka tidak akan ada tujuan yang telah ditetapkan yang akan tercapai. Menurut John Haggai, kepemimpinan adalah suatu tindakan disiplin yang memengaruhi orang-orang dalam kelompok untuk bergerak mencapai tujuan yang bermanfaat secara tetap (Siahaya, 2018, p. 2).

Masalahnya kepemimpinan bukanlah hal yang sederhana, karena berurusan dengan orang-orang, yakni berkaitan dengan bagaimana menggerakkan mereka. Kepemimpinan sama kompleksnya dengan manusia itu sendiri. Di samping itu, kepemimpinan sedang berhadapan dengan berbagai tantangan zaman masa kini, misalnya derasnya arus informasi karena perkembangan teknologi informasi. Tidak mengherankan jika kepemimpinan telah menjadi subjek kajian bagi banyak disiplin ilmu, seperti psikologi, sosiologi, politik, ilmu manajemen, dan lain-lain (Wijaya, 2018, p. 129). Bagaimanapun, kompleksitas kepemimpinan mengharuskannya untuk terus berkembang dengan melibatkan berbagai disiplin ilmu demi keberhasilan kepemimpinan itu sendiri.

Pada sisi lain, kepemimpinan Kristen atau gereja harus dibedakan dengan kepemimpinan di dunia sekuler. Kepemimpinan Kristen lebih unik, sebab melibatkan ilmu teologi dan Alkitab yang adalah firman Allah, bahkan Allah sendiri sebagai dasar dalam semua aspeknya. Kepemimpinan Kristen yang identik dengan kepemimpinan penggembalaan bukan soal aktivitas manajemen semata, tetapi juga menyangkut pertumbuhan orang-orang yang dipimpin, namun ironisnya, menurut pengamatan Daniel Ronda, masalah terbesar bagi sebagian pemimpin Kristen adalah kurangnya minat terhadap orang-orang, ketidakmampuan menjalin hubungan dengan rekanrekan, dan ketidakpedulian terhadap masalah-masalah emosional orang yang dipimpinnya (Ronda, 2011, p. 156, 157). Akibat yang pasti terjadi adalah kegagalan dalam kepemimpinannya. 
Kepemimpinan penggembalaan di era modern saat ini mendapat tantangan yang sangat besar. Derek J. Tidball mengemukakan beberapa alasannya yang pada umumnya menyangkut perubahan zaman yang sangat mencolok. Alasan-alasan itu antara lain: peranan gembala jemaat telah diambil alih oleh profesi-profesi sekuler seperti psikiater, dokter, konsultan, dan lain-lain; gambaran, struktur, dan pendekatan penggembalaan di dalam gereja dianggap kuno dan ketinggalan zaman; serta batasbatas penggembalaan sudah tidak jelas lagi karena adanya kesadaran bahwa Allah tidak terbatas dalam gereja dan kebenaran dapat ditemukan di luar gereja (Tidball, 1995, p. 15-21). Namun, apakah karena alasan perubahan zaman, kepemimpinan penggembalaan harus menyesuaikan diri dengan kepemimpinan sekuler yang terus berkembang?

Satu solusi yang diajukan adalah gereja perlu mengintegrasikan disiplin ilmu antara kepemimpinan rohani dan kepemimpinan sekuler (Yuliastomo dan Weismann, 2010, p. 6). Solusi ini mungkin ada benarnya, karena telah diakui secara luas bahwa kepemimpinan sekuler sebenarnya banyak menerapkan prinsip-prinsip kepemimpinan Alkitabiah. Tetapi ada hal yang perlu mendapat perhatian khusus, yaitu bahwa nilai-nilai yang mendasari kedua kepemimpinan ini sesungguhnya berbeda dan perbedaan itu menentukan bagaimana pengaplikasian kedua model kepemimpinan ini. Sebagaimana dikemukakan oleh Henry dan Richard Blackaby bahwa kepemimpinan rohani berbeda dari kepemimpinan pada umumnya, karena adanya sifat-sifat khusus dalam kepemimpinan rohani yang menentukan keberhasilan seorang pemimpin rohani (Blackaby, 2009, p. 24).

Masalah dan tantangan yang dihadapi dalam kepemimpinan penggembalaan, menurut penulis sebenarnya bukan disebabkan oleh kelemahan, kekurangan, apalagi kesalahan dari prinsip-prinsip Alkitabiah yang mendasarinya. Prinsip-prinsip yang disediakan oleh firman Tuhan cukup bahkan sangat memadai bagi kepemimpinan penggembalaan. Masalahnya, seperti hasil observasi dari Daniel Ronda di atas, bukan terletak pada prinsip-prinsipnya, melainkan pada orang yang menjalankan kepemimpinan itu, atau pemimpinnya. Pemimpin Kristen atau pemimpin rohani tidak maksimal di dalam menerapkan prinsip-prinsip kepemimpinan yang Alkitabiah.

Sekalipun gambaran, struktur, dan pendekatan kepemimpinan penggembalaan dianggap kuno dan ketinggalan zaman, namun prinsip-prinsipnya yang berdasarkan Alkitab tetap relevan bagi zaman modern ini, bahkan tetap relevan untuk segala zaman. Jika ingin kepemimpinan penggembalaan menjadi efektif, maka jalannya adalah menyelidiki Alkitab dan tokoh-tokoh kepemimpinannya (Blackaby, 2009, p. 6). Ada banyak contoh kepemimpinan di dalam Alkitab yang dapat dijadikan teladan bagi kepemimpinan penggembalaan dan yang terutama adalah teladan kepemimpinan yang diajarkan dan dipraktikkan oleh Gembala Agung, Yesus Kristus. Prinsip-prinsip kepemimpinan penggembalaan yang berasal dari Yesus Kristus itu bisa ditemukan dalam banyak kisah naratif pengalaman hidup Yesus dan pengajaranNya. Salah satu pengajaran Yesus yang paling utama dan relevan dengan kepemimpinan penggembalaan adalah yang tercatat dalam Injil Yohanes 10:1-21, 
yang dikenal dengan perumpamaan Gembala yang baik. Tulisan ini akan mengkaji Injil Yohanes 10:1-21 secara eksegesis untuk menemukan prinsip-prinsip kepemimpinan penggembalaan dan menarik implikasinya bagi kepemimpinan gereja.

\section{METODE}

Penelitian ini adalah penelitian kualitatif yang bersifat penelitian kepustakaan dengan menggunakan metode hermeneutik. Hermeneutik secara sederhana dapat didefinisikan sebagai penafsiran dan pada umumnya menunjuk proses teoritis dan metodologis untuk memahami makna yang terdapat dalam tanda-tanda dan simbolsimbol yang dipakai dalam komunikasi tertulis atau lisan (Sutanto, 2007, p. 3). Oleh karena objek dari penelitian ini adalah teks Alkitab, maka metode yang digunakan adalah hermeneutik Alkitab. Hermeneutik Alkitab adalah metode penafsiran yang bertujuan untuk menemukan maksud yang ingin disampaikan oleh penulis Alkitab (Sutanto, 2007, p. 8).

\section{HASIL DAN PEMBAHASAN}

\section{Analisis Teks Yohanes 10:1-21}

Teks Yohanes 10:1-21 adalah suatu perumpamaan dan penafsirannya yang disampaikan Yesus. Sekalipun disebut perumpamaan pada ayat 6, namun bukan perumpamaan biasa seperti yang banyak dicatat dalam Injil Sinoptik. Sebaliknya, ini hanyalah deskripsi umum tentang pemandangan dari dunia yang akrab di Palestina abad pertama (Michaels, 1989, p. 175). Kisah tentang gembala dalam perumpamaan ini tentu sangat dikenal oleh para pendengar-Nya saat itu, sebab gembala dan penggembalaan domba sudah umum di Palestina pada abad pertama. Tidak diragukan bahwa bagian ini langsung menyusul bagian sebelumnya, sekalipun tampaknya tema pasal 9 dan 10 berbeda. Pasal 9 berbicara tentang Yesus sebagai Terang dunia (Yoh. 9:5), sedangkan pasal 10 berbicara tentang Yesus sebagai Gembala. Namun pasal 9 sebenarnya mengandung dua peristiwa signifikan yang sama, pertama adalah peristiwa Yesus menyembuhkan orang buta sejak lahir dan yang kedua adalah reaksi orang-orang Farisi terhadap penyembuhan itu. Tema "Terang dunia" berkaitan dengan peristiwa pertama, sedangkan tema "Gembala" berkaitan dengan peristiwa kedua. Pasal 9 dan pasal 10 juga disatukan oleh komentar para pendengar yang merujuk pada peristiwa penyembuhan orang buta (ayat 21) sebagai respons dari perkataan Yesus tentang gembala.

Konteks Yohanes 10:1-21 adalah pertentangan Yesus dengan orang-orang Farisi, berkaitan dengan penyembuhan seorang yang buta sejak lahirnya (Yoh. 9). Tetapi Yohanes 10:1-21 tidak menafsirkan peristiwa penyembuhan orang buta sejak lahir itu, melainkan peristiwa yang menyusul penyembuhan itu, yakni penginterogasian orang buta yang telah disembuhkan itu dan pengusirannya dari 
rumah ibadat oleh orang-orang Farisi. Ini adalah respons Yesus atas sikap dan tindakan orang-orang Farisi terhadap orang buta yang telah disembuhkan-Nya.

Yohanes 10 adalah perluasan dari peristiwa yang terjadi dalam Yohanes 9. Dalam bagian terakhir pasal 9, Yesus bertentangan dengan orang-orang Farisi yang mengaku sebagai gembala umat, yaitu orang-orang yang duduk di kursi Musa (9:28) dan yang menyombongkan diri sebagai orang-orang yang memiliki pengetahuan tentang hukum Allah $(9: 16,29)$. Orang-orang yang mengaku gembala ini baru saja mengusir seekor domba yang miskin karena kejahatannya tidak mau mengakui dan percaya bahwa orang yang memelekkan matanya adalah orang berdosa. Perkataan Yesus di ayat yang terakhir merupakan teguran keras terhadap para gembala rohani yang angkuh ini, sebab sekalipun mereka memiliki hukum Musa dan kitab para nabi yang menunjukkan Kristus, mereka masih membutakan diri dengan prasangka yang kuat dan penolakan yang keras terhadap Yesus (Johnson, 1999, p. 157).

Itulah sebabnya Yesus melanjutkan dalam pasal 10 suatu penggambaran yang menunjukkan karateristik dari gembala yang sejati, sebagai lawan dari sikap dan tindakan dari orang-orang Farisi yang mengaku sebagai gembala. Latar dari perumpamaan Yesus adalah suatu desa kecil orang Yahudi (Kruse, 2003, p. 229). Analogi yang digambarkan oleh Yesus merupakan suatu prosedur harian yang dilakukan oleh seorang gembala Timur. Pada pagi hari, sang gembala memasuki kandang dombanya melalui pintu, memanggil domba-dombanya dan memimpin serta menuntun domba-domba itu ke padang penggembalaan. Sang gembala selalu siap melindungi domba-dombanya saat bahaya datang menghadang, bahkan rela mempertaruhkan nyawanya sendiri menghadapi serangan serigala dan bahayabahaya lain di padang, hingga dibawanya kembali domba-domba itu dengan selamat ke kandangnya pada malam hari (Tenney, 1996, p. 157).

Struktur Yohanes 10:1-21 dapat dibagi menjadi dua bagian besar yang masing-masing adalah perkataan langsung Yesus. Bagian pertama adalah ayat 1-5 yang berisi perumpamaan Yesus dan bagian kedua adalah ayat 7-18 yang berisi penafsiran Yesus atas perumpamaan-Nya itu. Sedangkan ayat 6 dan ayat 19-21 masing-masing adalah laporan tentang respons pendengar terhadap perumpamaan Yesus dan penafsiran Yesus. Setiap bagian ditandai dengan perkataan pembuka Yesus yang memakai formula: "Aku berkata kepadamu sesungguhnya...," suatu formula yang menunjukkan otoritas-Nya. Bagian kedua ayat 7-18 dapat dibagi lagi menjadi tiga bagian kecil yang menjelaskan perumpamaan Yesus pada bagian pertama: pertama, Yesus adalah pintu (ayat 7-10); kedua, Yesus adalah Gembala yang baik (ayat 8-16); dan ketiga, sumber otoritas Yesus (ayat 17-18). Strukturnya dapat diuraikan sebagai berikut:

1. Perumpamaan tentang Gembala (10:1-5)

Sisipan: Respons Pendengar (10:6)

2. Penafsiran Perumpamaan (10:7-18)

a. Yesus adalah Pintu (10:7-10)

b. Yesus adalah Gembala yang baik (10:11-16) 
c. Sumber Otoritas Yesus (10:17-18)

Sisipan: Respons Pendengar (10:19-21)

\section{Perumpamaan tentang Gembala (10:1-5) dan Respons Pendengar (10:6)}

Perumpamaan tentang Gembala (10:1-5)

Dalam perumpamaan Yesus tentang gembala, la mengontraskan antara gembala dan yang bukan gembala. Melalui kiasan-Nya ini, Yesus tidak sedang mengajarkan suatu penggembalaan yang lembut, melainkan suatu teguran dan dakwaan yang keras terhadap orang-orang yang mengaku sebagai gembala, padahal mereka sebenarnya bukan gembala (Fredrikson, Ogilvie, 1985, p. 174). Yesus menguraikan kiasan-Nya secara unik, yakni uraian tentang yang bukan gembala (ayat 1 dan 5) mengapit uraian tentang gembala (ayat 2-4), kemudian ayat 1 dan 2 membentuk pola yang sama dengan ayat 4 dan 5 , yaitu saling kontras satu sama lain. Dari diagram (gambar 1 di bawah) jelas terlihat perbedaan antara gembala dan bukan gembala. Perbedaan yang paling mencolok adalah gembala memiliki otoritas sebagai gembala (ayat 3), sedangkan yang bukan gembala tidak memilikinya.

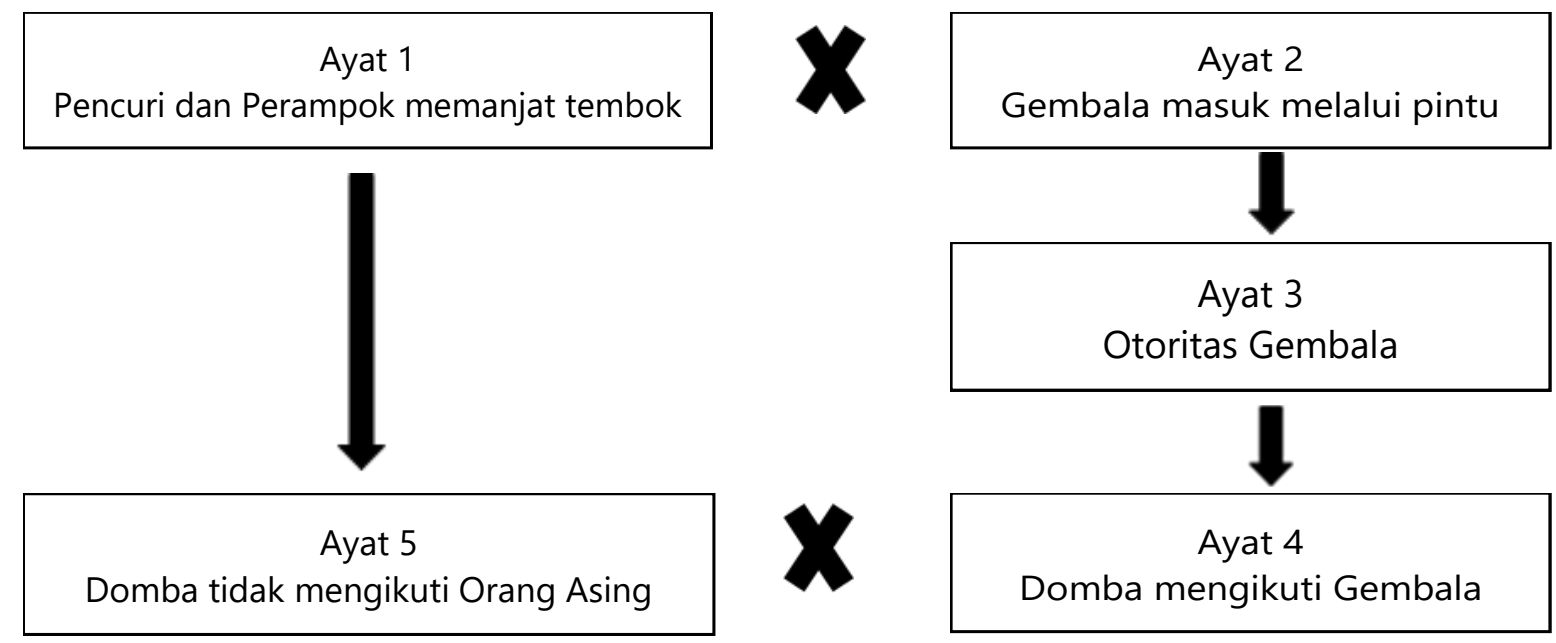

\section{Gambar 1. Diagram Perumpamaan Tentang Gembala}

Dengan demikian, perumpamaan ini juga membentuk kiastik dengan puncaknya pada ayat 3 yang menjelaskan tentang penjaga membuka pintu untuk gembala. Ini berbicara tentang otoritas yang diberikan kepada seorang gembala. Hal ini menunjukkan betapa pentingnya otoritas gembala dalam pikiran Yesus. Kepemilikan otoritas adalah penentu apakah seseorang dapat disebut gembala atau tidak. Berikut ini struktur kiastik dari perumpamaan tentang gembala:

A Pencuri/perampok memanjat tembok (ayat 1)

B Gembala masuk melalui pintu (ayat 2)

C Penjaga membuka pintu (otoritas; ayat 3) 


\section{$B^{\prime} \quad$ Domba mengikuti gembala (ayat 4)}

\section{$A^{\prime}$ Domba tidak mengikuti orang asing (ayat 5)}

Bryant and Krause, menjelaskan tentang situasi kandang domba di Timur yang biasanya terbuka ke langit dengan dipagari oleh alang-alang atau tembok batu untuk memberikan perlindungan bagi domba-domba dari pencuri, perampok, serigala, atau binatang buas lainnya. Ada pintu besar untuk gembala bersama domba-domba keluar masuk, yang dijaga oleh seorang penjaga. Penjaga pintu memberikan izin masuk ke kandang hanya untuk orang yang berhak atau memiliki otoritas untuk masuk. Kadang-kadang, perampok atau binatang buas memanjat tembok pagar kandang untuk mencuri atau membinasakan domba-domba. Hanya ada satu jalan masuk ke kandang, yaitu melalui pintu. Semua yang masuk ke kandang selain melalui pintu, hanya memiliki tujuan "mencuri domba" dalam arti membawa domba pergi melalui kepemimpinan yang menipu (Bryant and Krause, 1998, p. Jn. 10:1). Mereka adalah pencuri atau perampok yang bertindak untuk kepentingan diri sendiri, bukan kepentingan kawanan domba. "Tetapi siapa yang masuk melalui pintu, ia adalah gembala domba" (ayat 2). Orang yang memiliki otoritas yang sah masuk ke kandang domba dengan cara yang benar, yaitu melalui pintu. Dialah gembala domba yang sejati, pintu dibukakan untuknya sebab ia dikenali oleh penjaga pintu. Keabsahannya sebagai gembala semakin dibenarkan oleh fakta bahwa domba-domba mendengarkan suaranya (ayat 3). Domba-domba hanya mendengarkan suara gembalanya, sebab mereka mengenal suaranya. Hal ini bisa terjadi sebab hubungan antara gembala dan domba-dombanya adalah hubungan yang dekat dan berlangsung lama, hingga gembala dapat memanggil mereka dengan namanya masing-masing. Domba-domba mendengar suara gembala dengan ketaatan, sehingga gembala dapat menuntun mereka keluar dari kandang dengan tenang dan tertib.

Setelah domba-dombanya dibawa keluar, kemudian gembala berjalan di depan mereka dan domba-domba itu mengikuti dia, karena mereka mengenal suaranya (ayat 4). Domba-domba taat mengikuti sang gembala, ke mana pun dia pergi. Artinya, gembala adalah pemimpin yang memimpin domba-dombanya ke tujuan, yaitu ke padang rumput yang hijau dan ke air yang tenang (Mzm. 23:2). Kata yang

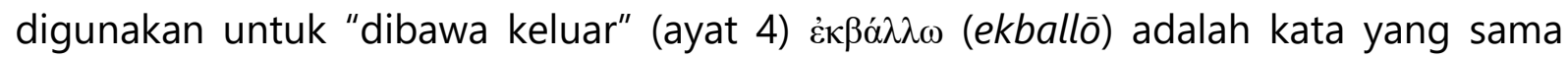
dengan yang digunakan untuk menyatakan para pemimpin "mengusir" orang buta yang telah disembuhkan itu dari rumah ibadat (9:34-35). Gambaran gembala yang menuntun domba-domba keluar (ayat 3) untuk menemukan padang rumput dan air dengan demikian menafsirkan apa yang baru saja terjadi pada orang yang dilahirkan buta.

Sebaliknya, hal yang berlawanan akan terjadi jika ada seorang asing yang ingin membawa pergi domba-domba itu. Orang asing bisa saja adalah gembala dari kawanan domba yang lain, atau seorang pencuri dan perampok (ayat 1). Dombadomba tidak akan mengikuti seorang asing, bahkan mereka lari dari padanya, karena suara orang-orang asing tidak dikenal oleh mereka (ayat 5). Sekalipun seorang asing 
berusaha menyamai sang gembala dengan memakai pakaian gembala dan berusaha meniru panggilannya, dia hanya akan berhasil membuat domba-domba melarikan diri darinya, sebab domba-domba mengetahui suara gembalanya, mereka tidak tahu dan tidak akan menanggapi suara orang asing (Morris, 1995, p. 448). Domba akan diketahui oleh siapa yang mereka tahu atau kenal, suatu gambaran yang indah tentang kedaulatan ilahi dalam panggilan gembala dan tanggapan manusia dalam mendengar, mengetahui, dan mengikuti (Whitacre, 1999, p. 256).

\section{Respons Pendengar (10:6)}

Perumpamaan tentang gembala dan domba ini ditujukan oleh Yesus kepada orang-orang Yahudi, secara khusus para pemimpin, orang-orang Farisi yang berurusan dengan orang buta sejak lahir yang telah disembuhkan oleh Yesus. Namun, mereka tidak mengerti apa maksud Yesus berkata demikian kepada mereka (ayat 6). Pasti mereka sudah paham dan akrab dengan gagasan tentang gembala sebagai pemimpin rohani, tetapi yang tidak mereka pahami adalah penerapannya. Itulah sebabnya, Yesus kemudian menjelaskannya lebih lanjut.

\section{Penafsiran Perumpamaan (10:7-18) dan Respons Pendengar (10:19-21)}

\section{Yesus adalah Pintu (10:7-10)}

Yesus menyebut beberapa pribadi dalam perumpamaan-Nya, yaitu pencuri, perampok, orang asing, penjaga pintu, dan gembala domba. Tetapi menariknya, Yesus memulai uraian penafsiran dari kiasan-Nya dengan penjelasan tentang pintu, bukan pribadi-pribadi itu. Pintu ke domba-domba adalah kiasan dari diri-Nya sendiri.

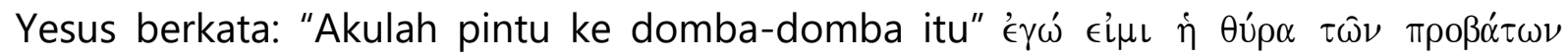

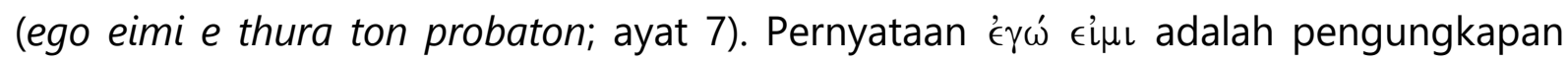

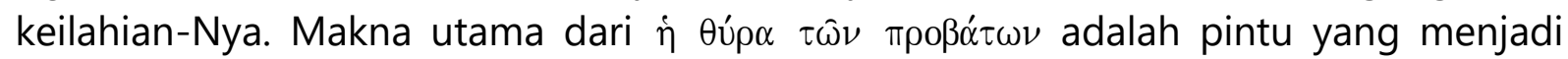
akses gembala untuk membawa domba-domba masuk dan keluar dari kandangnya. Ketika Yesus menyatakan bahwa Dia adalah pintu ke domba-domba, Yesus menyatakan diri-Nya adalah pintu akses yang sah, di mana gembala yang sejati harus lewat untuk masuk ke "kandang" kaum Israel. Semua orang yang datang sebelum Yesus (ayat 8) merujuk kepada para pemimpin Yahudi, ahli Taurat, dan orang-orang Farisi yang mengaku sebagai pemimpin rohani, namun sesungguhnya mereka adalah pencuri dan perampok.

Yesus kembali menegaskan pada ayat 9, "Akulah pintu." Yesus adalah satusatunya pintu, tetapi maknanya di sini lebih kepada pintu yang harus digunakan oleh domba-domba. Gagasannya adalah bahwa Yesus merupakan satu-satunya sarana yang melaluinya domba dapat masuk ke kandang dengan selamat (ayat 9a) dan keluar mendapatkan padang rumput yang hijau (ayat 9b). Gambarannya adalah melalui Yesus, domba-domba mendapatkan semua kebutuhannya untuk hidup. Bahkan Yesus memberikan penegasan bahwa Dia datang supaya mereka mempunyai 
hidup dan mempunyainya dalam segala kelimpahan. Secara metaforis, kehidupan dalam segala kelimpahan menunjuk pada kehidupan domba yang gemuk, puas, berkembang, dan bebas dari bahaya; suatu kiasan bagi kehidupan terbaik yang bisa dibayangkan dari kehidupan umat Tuhan (Carson, 1991, p. 385). Salah satu contohnya adalah kesembuhan yang dialami oleh orang yang dilahirkan buta. Sangat jauh berbeda dengan pencuri yang datang hanya untuk mencuri dan membunuh dan membinasakan.

Perkataan Yesus ini sejalan dengan perkataan-Nya dalam Yohanes 14:6, "Akulah jalan dan kebenaran dan hidup. Tidak ada seorang pun yang datang kepada Bapa, kalau tidak melalui Aku." Penegasannya adalah hanya ada satu cara untuk menerima kehidupan kekal, hanya ada satu sumber makanan rohani, dan hanya ada satu dasar untuk keamanan rohani, yaitu Yesus (Carson, 1991, p. 385). Pada akhirnya jangkauan pernyataan Yesus sebagai pintu harus diperluas mencakup bukan hanya dombadomba, tetapi juga para gembala, yaitu para pemimpin umat. Yesus adalah pintu kehidupan bagi gembala dan domba. Dalam pengertian ini, Yesus juga menyatakan diri-Nya sebagai gembala (ayat 11). Yesus adalah Gembala Agung yang menggembalakan umat-Nya termasuk para pemimpin sebagai gembala. Konteks di Timur biasanya para gembala memiliki kumpulan domba yang besar, dan yang mengatasi keseluruhan kawanan domba adalah Gembala Agung. Gembala Agung membawahi beberapa gembala bawahan yang masing-masing diberi seberapa banyak domba yang dapat dia tangani. Gembala bawahan ini bertanggung jawab atas domba-domba ini dan bertanggung jawab kepada Gembala Agung (Conner, 2004, p. 386-387).

\section{Yesus adalah Gembala Yang Baik (10:11-16)}

Yesus mengindentifikasi diri-Nya bukan sekadar sebagai gembala, namun sebagai gembala yang baik (ayat 11). Sekarang Yesus mengembangkan lagi penjelasan-Nya tentang kiasan gembala. Sebelumnya Yesus hanya menyinggung perbedaan antara gembala dan yang bukan gembala, tetapi di sini Yesus juga melibatkan gembala upahan dan bukan pemilik domba. Gembala yang baik adalah gembala yang memberikan nyawanya bagi domba-dombanya, sedangkan seorang upahan dan bukan pemilik domba tidak akan melakukan hal itu (ayat 12-13). Ketika bahaya datang mengancam domba-domba, ia bukannya memberikan nyawanya, tetapi malahan menyelamatkan nyawanya sendiri dan membiarkan domba-domba itu binasa. la berbuat seperti itu karena ia adalah orang upahan dan bukan pemilik domba, sehingga ia tidak memperhatikan domba-domba itu. Yesus merujuk pada para pemimpin Yahudi yang tidak peduli dengan tanggung jawab mereka untuk memelihara umat.

Sebaliknya, Yesus tidak berbuat demikian. Yesus mempertentangkan diri-Nya dengan orang upahan yang bukan gembala dan yang bukan pemilik domba-domba. Melalui pertentangan ini, Yesus menekankan bahwa diri-Nya adalah pemilik dombadomba. Yesus menyebut diri-Nya sebagai gembala yang baik, sebab la memberikan 
nyawa-Nya bagi domba-domba-Nya (ayat 15). Seorang gembala yang sejati siap mempertaruhkan nyawanya demi domba-dombanya. Ungkapan "memberikan nyawanya bagi domba-dombanya" mengandung unsur sukarela dari Yesus untuk memenuhi tujuan yang telah ditentukan bagi-Nya (ayat 18). Kata "bagi" atau "untuk" u̇т̇є $\rho$ (huper) domba-domba, menyarankan bahwa ini adalah tindakan pengorbanan (Carson, 1991, p. 385). Menurut Kruse, sebenarnya dalam kenyataan akan jarang, jika pernah ada, gembala benar-benar mati untuk melindungi domba-dombanya, tetapi di sini Yesus memperluas gambaran di luar batas normal dan menunjuk ke masa depan ketika la benar-benar mati bagi umat-Nya (Kruse, 2003, p. 229). Kematian Yesus memberikan kehidupan bagi domba-domba-Nya.

Yesus adalah gembala yang baik, sebab la mengenal domba-domba-Nya dan domba-domba-Nya mengenal-Nya (ayat 14). Yesus memiliki hubungan timbal balik dan intim dengan domba-domba-Nya dan karena itu la memperhatikan mereka. Keintiman hubungan Yesus dan domba-domba-Nya menjadi jelas, karena hubungan itu disamakan dengan hubungan-Nya dengan Bapa-Nya (ayat 15) yang dilandasi oleh kasih. Dengan kata lain, ada keintiman yang penuh kasih di antara gembala dengan domba-domba; Gembala mengenal yang lemah dan yang kuat, yang keras kepala dan yang tunduk, kesakitan dan kebutuhan setiap domba, sebaliknya domba-domba mengenal dan memercayai gembala mereka, nada suaranya, caranya mengarahkan mereka ke padang rumput, keberaniannya dalam menghadapi bahaya (Fredrikson, Ogilvie, 1985, p. 174).

Satu lagi perluasan dilakukan Yesus yang dinyatakan pada ayat 16 bahwa ada domba-domba lain miliknya, yang bukan dari kandang ini yang harus la gembalakan juga. "Kandang ini" merujuk pada kata "kandang" dalam ayat 1-5 yang mewakili orang-orang Yahudi. Jadi ketika Yesus mengatakan bahwa la memiliki domba lain yang bukan dari kandang ini, itu pasti merujuk kepada bangsa-bangsa lain. Dombadomba lain ini juga akan mendengar suara Yesus dan akan disatukan menjadi satu kawanan dengan satu gembala, yaitu Yesus. Yesus juga memberikan nyawa-Nya untuk domba-domba ini. Dengan demikian, keselamatan yang dari orang Yahudi memang pertama-tama diberitakan kepada orang-orang Yahudi, namun tetap terbuka untuk bangsa-bangsa lain juga, dan ini adalah penggenapan nubuat mesianis dan dasar dari misi non-Yahudi (Carson, 1991, p. 388).

\section{Sumber Otoritas Yesus (10:17-18)}

Pada bagian akhir dari penafsiran kiasan-Nya, Yesus menjelaskan lebih detail tentang sifat pemberian nyawa-Nya untuk domba-dombanya (ayat 17-18). Satu aspek dari motivasi Yesus menyerahkan nyawa-Nya adalah bahwa itu menjadi alasan Bapa mengasihi-Nya. Artinya, kematian Yesus adalah kehendak Allah dan karena la secara sempurna selaras dengan kehendak Allah, maka la melangkah menuju kematian itu, sehingga dalam hal ini kasih Bapa adalah pengakuan dari pihak Bapa tentang komunitas yang sempurna di antara mereka (Morris, 1995, p. 456). Ini menyiratkan bahwa Yesus menyerahkan nyawa-Nya dalam ketaatan kepada Bapa- 
Nya yang dikaitkan dengan kasih Bapa kepada-Nya. Oleh karena itu, Yesus menyerahkan nyawa-Nya untuk menerimanya kembali. Kematian Yesus tidak dapat dipisahkan dari kebangkitan-Nya, la mati untuk dibangkitkan. Yesus berkuasa atas kematian-Nya dan juga kebangkitan-Nya. Kematian-Nya bukan paksaan, tidak seorang pun mengambil nyawa-Nya, tetapi Yesus menyerahkan nyawa-Nya menurut kehendak-Nya sendiri. Artinya, Yesus mati dengan kerelaan-Nya sendiri. Perkataan Yesus yang terakhir: "Inilah tugas yang Kuterima dari Bapa-Ku" (ayat 18), menyatakan bahwa otoritas pelayanan-Nya di dunia berasal dari Bapa-Nya dan sejak awal la sudah tahu bahwa puncak pelayanan-Nya di dunia adalah tindakan ketaatan-Nya, yaitu menyerahkan diri-Nya ini demi kawanan domba.

\section{Respons Pendengar (10:19-21)}

Perkataan Yesus melalui perumpamaan dan penafsiran-Nya menuai respons dari pendengar-Nya (ayat 19-21). Timbul pertengkaran di antara orang-orang Yahudi dan mereka terpecah menjadi dua kubu. Sebagian besar di antara mereka menyebut Yesus kerasukan setan dan gila, karena itu Yesus tidak pantas untuk didengarkan, sedangkan yang lain tidak sependapat dengan alasan setan tidak dapat memelekkan mata orang-orang buta.

\section{Prinsip-Prinsip Kepemimpinan Penggembalaan Berdasarkan Yohanes 10:1-21 dan Implementasinya dalam Kepemimpinan Gereja}

Perumpamaan tentang gembala yang dikemukakan Yesus dalam teks Yohanes 10:1-21 merupakan respons-Nya terhadap orang-orang Farisi yang mengaku sebagai pemimpin atau gembala umat, namun tidak bertindak selayaknya gembala. Mereka telah mengusir salah seorang umat, yaitu orang buta yang telah disembuhkan Yesus, karena ia percaya bahwa Yesus datang dari Allah (Yoh. 9:33). Melalui perumpamaan ini Yesus mengungkapkan karakteristik dari gembala yang sejati, sebagai kontras dari sikap dan tindakan orang-orang Farisi. Karena itu, perumpamaan ini menunjukkan prinsip-prinsip kepemimpinan penggembalaan yang dapat diimplementasikan dalam kepemimpinan gereja. Beberapa prinsip itu adalah prinsip panggilan Allah, prinsip kesetaraan, prinsip pemeliharaan, prinsip pengorbanan, dan prinsip perluasan kerajaan Allah.

\section{Panggilan Allah (10:2-3, 7)}

Isu mengenai panggilan dalam kepemimpinan penggembalaan masih menjadi bahan diskusi dan pergumulan di dalam gereja. Pertanyaannya adalah masih relevankah berbicara tentang panggilan pada masa kini? Menurut Friesen, sekalipun Alkitab dipenuhi dengan kisah-kisah di mana Allah memanggil orang-orang tertentu untuk melaksanakan pelayanan khusus, seperti Musa, Yeremia, dan Yesaya, namun semua itu tidak bisa menjadi contoh pada masa kini, sebab Allah tidak lagi memanggil orang-orang dengan cara yang sama pada zaman Alkitab, yaitu berbicara dengan suara yang dapat mereka dengar sehingga tidak ada keraguan bagi mereka 
mengenai kehendak Allah; sangat berbeda dengan saat ini mengingat betapa sulitnya menemukan kehendak Allah (Lutzer, 2010, p. 8). Selain itu, penekanan pada panggilan untuk orang-orang tertentu dalam pelayanan tampaknya tidak sejalan dengan penekanan Alkitab pada kepentingan setiap anggota tubuh Kristus.

Tetapi Lutzer memberikan keyakinan tentang sebuah panggilan berdasarkan kepercayaannya bahwa "Allah memanggil beberapa orang yang tentunya lebih khusus daripada panggilan seperti yang ditujukan kepada semua orang percaya. Ada sebuah panggilan yang lebih dari sekadar bakat untuk melayani dan bahkan lebih dari sebuah kerinduan untuk berkhotbah atau mengajar" (Lutzer, 2010, p. 10). Sekalipun panggilan masih seperti suatu misteri bagi orang Kristen, tetapi itu tidak berarti panggilan Allah tidak ada lagi. Definisi Lutzer tentang panggilan menolong untuk memperjelas karakteristik dari panggilan itu: "Panggilan Allah adalah keyakinan dari dalam hati yang diberikan oleh Roh Kudus dan diteguhkan oleh firman Allah serta anggota tubuh Kristus" (Lutzer, 2010, p. 12). Tiga karakteristik penting dari panggilan adalah adanya keyakinan dari dalam hati oleh pekerjaan Roh Kudus, adanya peneguhan dari firman Allah, dan peneguhan dari sesama orang Kristen.

Prinsip panggilan Allah bagi kepemimpinan penggembalaan masih relevan dan penting pada masa kini. Prinsip ini tergambar di dalam Yoh. 10:2, "tetapi siapa yang masuk melalui pintu, ia adalah gembala domba," dan Yoh. 10:7, Yesus adalah pintu ke domba-domba. Gembala memasuki tugas penggembalaan atau tugas pelayanan pekerjaan Tuhan hanya melalui satu-satunya pintu yang sah, yaitu Yesus Kristus. Kepemimpinan penggembalaan harus sesuai dengan hak yang Tuhan berikan melalui panggilan dan ketetapan Tuhan kepadanya. Panggilan berbicara tentang otoritas. Hal ini sesuai dengan pesan Paulus kepada para penatua jemaat di Efesus, "Karena itu jagalah dirimu dan jagalah seluruh kawanan, karena kamulah yang ditetapkan Roh Kudus menjadi penilik untuk menggembalakan jemaat Allah yang diperoleh-Nya dengan darah Anak-Nya sendiri" (Kis. 20:28). Dengan demikian, otoritas kepemimpinan yang dimiliki seorang gembala dalam tugas penggembalaan adalah otoritas yang berasal dari Tuhan dan harus dipertanggungjawabkan kepada Tuhan.

Sedangkan orang yang masuk ke dalam kandang domba dengan tidak melalui pintu, tetapi dengan memanjat tembok, ia adalah seorang pencuri dan seorang perampok (10:1). Demikian pula orang yang masuk dalam kepemimpinan penggembalaan tanpa hak dan panggilan Tuhan, niscaya akan mengacaukan dan menghancurkan jemaat Tuhan. Tanpa panggilan Allah, seseorang tidak akan bertahan dalam kepemimpinan penggembalaan. Tantangan dan pergumulan dalam penggembalaan akan segera membuatnya melarikan diri. Sudgen dan Wiersbe mengatakan:

Pekerjaan pelayanan dipandang sulit dan terlalu banyak tuntutan bagi siapa saja bila tidak didasarkan pada panggilan ilahi. Terlalu banyak orang yang dengan mudah memasuki pelayanan tetapi kemudian meninggalkannya, karena mereka tidak merasakan dorongan ilahi yang mengiringi panggilan mereka. Hanya 
panggilan dari Allah saja yang dapat memberi Anda keberhasilan apabila pelayanan dirasa sangat berat/sukar (Sudgen, Wiersbe, 2009, p. 9).

Dengan demikian dapat disimpulkan bahwa panggilan Allah dalam kepemimpinan penggembalaan adalah sesuatu yang krusial dan tidak bisa diabaikan. Bahkan menurut Sudibyo, panggilan Allah adalah kompetensi terbaik dalam pelayanan penggembalaan (Sudibyo, 2019, p. 53). Tidak akan ada yang mampu dengan sungguh-sungguh memenuhi tanggung jawab kepemimpinan penggembalaan, jika tidak ada keyakinan dari dalam dirinya akan panggilan Allah.

\section{Kesetaraan $(10: 7,9)$}

Prinsip kesetaraan dalam kepemimpinan penggembalaan yang dimaksud di sini adalah bahwa pemimpin gereja sebagai gembala harus menyadari kesetaraan antara dirinya dan orang-orang yang dilayaninya di hadapan Tuhan. Prinsip kesetaraan ini ditemukan dalam fakta bahwa Yesus Kristus adalah pintu bagi siapa pun, baik bagi gembala (10:7), maupun bagi domba (10:9) untuk keselamatan dan kehidupan yang berkelimpahan. Semua orang harus melalui Yesus untuk keselamatan dan kehidupan. Seorang gembala juga adalah domba. Gembala tidak lebih tinggi dari orang yang dilayaninya, tetapi setara dengan orang itu dan ia melayani dengan cara yang paling efektif ketika ia dapat berbagi kelemahan dan ketakutannya sendiri kepada orang yang dilayaninya (Tidball, 1995, p. 383).

Menurut Bons-storm, sekalipun gembala "mewakili Tuhan," namun itu tidak berarti ia berperan sebagai "pengantara" antara jemaat dan Gembala yang baik, maksudnya adalah gembala tidak boleh berdiri di tengah-tengah jemaat dan Tuhan, sehingga menghalangi jalan jemaat untuk bertemu dengan Tuhan secara langsung (Bons-Storm, 2008, p. 27). Gembala berperan sebagai pembimbing rohani yang menemani jemaat mengarungi kehidupan mereka, termasuk ketika mereka berada dalam lembah-lembah kekelaman atau dalam kesulitan dan penderitaan hidup (Mzm. 23). Itulah yang diteladankan oleh Gembala yang baik, bukan seperti gembala upahan yang meninggalkan domba-dombanya saat dalam kesulitan.

Pembimbing rohani adalah peran yang dapat dilakoni oleh seorang gembala jemaat dalam prinsip kesetaraan ini, sebab ada kebutuhan jemaat akan bimbingan rohani karena ketidakmampuan mereka memahami pengalaman hidup dan kehadiran Allah di dalamnya. Bimbingan rohani adalah suatu proses mengarahkan orang dan kelompok untuk melampaui realitas yang dapat dilihat kepada realitas Allah sebagai satu-satunya pribadi yang memungkinkan seseorang untuk memahami situasinya saat ini (Rice, 2006, p. 58). Inilah peran kepemimpinan penggembalaan dalam jemaat berdasarkan prinsip kesetaraan.

\section{Pemeliharaan (10:9-10)}

Prinsip pemeliharaan dalam kepemimpinan penggembalaan adalah prinsip yang berkaitan dengan tugas dan tanggung jawab pemimpin gereja sebagai gembala 
umat. Penggembalaan adalah tugas pelayanan untuk memelihara jemaat, yaitu secara rohani memelihara jiwa jemaat. Sama seperti tugas seorang gembala domba adalah memelihara domba-domba, yang berkaitan dengan memberi mereka makan, memberi perlindungan, dan merawat yang sakit agar mereka hidup dan selamat. Sebagai gembala, Yesus mengatakan bahwa hanya melalui Dia domba-domba akan selamat dan menemukan padang rumput, dan bahwa Dia datang supaya mereka mempunyai hidup dalam segala kelimpahan (10:9-10). Demikianlah kepemimpinan penggembalaan harus menyadari tugas utama penggembalaan, yaitu memelihara jiwa orang-orang sehingga mereka menemukan kesembuhan mereka sendiri sebagai karunia dari Allah (Rice, 2006, p. 75).

Pemeliharaan berkaitan dengan pertumbuhan. Pemeliharaan jemaat berkorelasi dengan pertumbuhan jemaat, khususnya pertumbuhan secara kualitas. Bons-Storm menyatakan bahwa tujuan terakhir dari penggembalaan adalah supaya jemaat Yesus Kristus dibangun, dalam pengertian semua anggota jemaat menjadi anggota yang hidup, yang tahu akan panggilannya, sehingga jemaat itu menjadi suatu jemaat yang hidup dan menarik, seperti lampu di atas gunung (Bons-Storm, 2008, p. 7). Jika jemaat tidak dibangun, maka pasti ada masalah dalam kepemimpinan penggembalaan. Salah satunya mungkin tugas dan tanggung jawab pemeliharaan tidak dilaksanakan dengan baik dalam kepemimpinan gembala.

Dalam konteks pertumbuhan jemaat, gembala jemaat bertanggung jawab memberi makan jemaat, yaitu memberi makanan bagi jiwa mereka dengan firman Allah yang diterangkan agar dipahami dan dilakukan dengan setia. Pengajaran firman Allah kepada jemaat menjadi hal yang pokok karena melalui firman Allah, jemaat dibangun dalam iman oleh pengenalan yang benar akan Allah. Firman Tuhan harus benar-benar dapat menyentuh dan dihidupi dalam kehidupan keseharian jemaat. Dalam penggembalaan, gembala memberitakan firman Tuhan melalui percakapan penggembalaan dan menyajikannya sebagai firman Allah yang relevan untuk kehidupan sehari-hari (Bons-Storm, 2008, p. 18).

Prinsip pemeliharaan menuntut gembala mengenal domba-dombanya, sama seperti Yesus sebagai gembala yang baik mengenal domba-domba-Nya dan dombadomba-Nya mengenal-Nya (Yoh. 10:14). Kepemimpinan gembala yang sejati tidak boleh mengabaikan tuntutan ini. Gembala harus mengenal setiap anggota jemaatnya, karena merekalah yang dilayaninya, jiwa merekalah yang hendak dipelihara. Rice mengatakan, "Memelihara jiwa melibatkan berbagai macam perhatian lebih dari sekadar pikiran dan tubuh. Karena pengetahuan tentang jiwa manusia hanya datang dari hubungan dengan Allah, melayani jiwa-jiwa berarti mengurus cara orang-orang berhubungan dengan Allah dengan memberikan perhatian kepada kehidupan rohani mereka" (Rice, 2006, p. 72). Seorang gembala tidak akan dapat melayani jemaatnya dengan cara seperti ini, tanpa pengenalan yang intim secara timbal balik antara dia dan jemaatnya. Gembala memerlukan pengetahuan yang mendalam akan jemaatnya dan jemaatnya perlu merasa yakin akan kepemimpinannya. Salah satu cara yang dapat dilakukan oleh gembala untuk menciptakan pengenalan yang intim dengan 
jemaatnya adalah dengan melakukan perkunjungan pastoral, yaitu mengunjungi jemaatnya secara teratur (Bons-Storm, 2008, p. 18).

Seorang gembala wajib melayani kawanan domba, mencari yang hilang, membalut yang terluka, menguatkan dan menyembuhkan yang sakit (Yeh. 34:16). Secara rohani gembala jemaat merawat jemaat yang sakit, dalam arti jemaat yang dalam pergumulan. Gembala harus mampu mendeteksi pergumulan yang dihadapi oleh setiap anggota jemaat dan memberi pertolongan. Pertolongan dapat berupa memberi perhatian yang khusus dan lebih, konseling, mendukung dalam doa, memberi nasihat melalui firman Tuhan, dan lain-lain. Hal ini dilakukan agar jemaat mampu menanggapi, menghadapi, dan menjalani pergumulan mereka sesuai dengan kehendak Tuhan. Gembala jemaat mampu mewujudkan semua ini hanya melalui perkunjungan pastoral sebagai alat utama dalam pelaksanaan penggembalaan jemaat.

Seorang gembala juga adalah penjaga dan pelindung bagi domba-domba dari musuh-musuh mereka dan senantiasa memberi peringatan kepada mereka akan hal itu. Artinya, selain menjamin pertumbuhan jemaat, tugas dan tanggung jawab pemeliharaan ini juga mencakup jaminan keamanan bagi jemaat dalam konteks serangan ajaran sesat. Gembala harus berperan sebagai pengawas/penjaga dan pelindung untuk menyelamatkan jemaat dari bahaya. Mengawasi jemaat dalam pelaksanaan ibadah dan ketetapan Injil serta melindungi jemaat dari berbagai ajaran palsu yang menyesatkan (Ef. 4:11-16). Gembala harus mempersiapkan dan memperlengkapi jemaat dalam menghadapi rupa-rupa ajaran yang tidak sesuai dengan kebenaran firman Tuhan, salah satunya melalui pengajaran firman Tuhan secara intensif dan terfokus, agar dalam menghadapi penyesatan jemaat mampu membentengi diri sendiri dan menolaknya.

\section{Pengorbanan (10:11)}

Yesus mendeskripsikan gembala yang baik sebagai gembala yang rela memberikan nyawanya bagi domba-dombanya (10:11). Gembala yang baik akan mempertaruhkan nyawanya sendiri demi keselamatan domba-dombanya. Gembala yang baik berdiri di depan menghadapi serigala yang datang untuk menerkam dan mencerai-beraikan domba-domba itu. la tidak melarikan diri dan meninggalkan domba-domba menghadapi bahaya. Ini adalah suatu gambaran bahwa tugas sebagai gembala yang sejati itu tidaklah mudah, karena banyak menuntut pengorbanan. la harus siap mengorbankan segala-galanya, bahkan hidupnya sendiri. Yesus menyebut diri-Nya sebagai gembala yang baik, yang menyerahkan nyawa-Nya sebagai ganti domba-domba supaya mereka mempunyai hidup yang dari Allah, yaitu hidup yang kekal. Ini adalah pengorbanan, sebab Yesus menyerahkan nyawa-Nya dengan sukarela karena kasih dan ketaatan-Nya kepada bapa-Nya. Pelayanan penggembalaan adalah mengorbankan diri sendiri (Tidball, 1995, p. 99).

Setiap gembala harus mengikuti teladan Gembala yang baik ini. Seorang gembala jemaat harus siap menyerahkan nyawanya bagi jemaat, yang berarti siap 
berkorban demi kepentingan jemaat yang digembalakannya. Prinsip pengorbanan dalam kepemimpinan penggembalaan adalah prinsip yang tidak dapat dihindari, sebab prinsip itu sudah terkandung dalam panggilannya sebagai gembala. Seorang gembala harus menyadari bahwa ia tidak dipanggil sebagai orang upahan dan tidak melayani karena keuntungan (1 Ptr. 5:2; 1 Tim. 3:3). Sesungguhnya ia adalah hamba Gembala Agung dan dipanggil untuk melayani-Nya dengan kerelaan dan pengabdian diri (1 Ptr. 5:2). Gembala Agung telah berkorban untuk dirinya, ia pun wajib berkorban untuk jemaat yang dipercayakan kepadanya.

Tanpa menghidupi prinsip pengorbanan dalam kepemimpinannya, maka seorang gembala tidak akan mampu bertahan dalam pelayanan penggembalaan. Betapa tidak, tugas penggembalaan bukanlah tugas yang ringan jika dinilai dari sisi kemanusiaan karena butuh banyak pengorbanan (Prajogo, 2019, p. 4). Sebagaimana seorang gembala domba yang selalu bersama domba-dombanya dari pagi sampai malam, berjalan bersama kawanan dombanya untuk mencari padang rumput dan sumber air yang tenang. Demikian pula seorang gembala jemaat harus senantiasa berjaga-jaga atas jiwa umat gembalaannya, sebab itu adalah tanggung jawabnya (Ibrani 13:17).

\section{Perluasan Kerajaan Allah (10:16)}

Yesus berkata: "Ada lagi pada-Ku domba-domba lain, yang bukan dari kandang ini; domba-domba itu harus Kutuntun juga dan mereka akan mendengarkan suara-Ku dan mereka akan menjadi satu kawanan dengan satu gembala" (10:16). Kawanan domba Yesus memang berpangkal pada orang-orang Yahudi, namun tidak terbatas hanya pada orang-orang Yahudi, karena di sini Yesus menekankan sifat universal dari kawanan domba-Nya. Yesus memperluas jangkauan pelayanan-Nya meliputi domba-domba lain yang masih sesat dan belum kembali ke kandang yang benar. Domba-domba lain adalah bangsa-bangsa lain yang juga harus disatukan dalam kandang Gembala yang baik. Domba-domba ini adalah milik Sang Gembala yang harus dituntun atau digembalakan juga.

Sama seperti Yesus, kepemimpinan penggembalaan harus senantiasa memikirkan dan berusaha untuk memperluas jangkauan pelayanannya keluar dari ruang lingkup jemaatnya, agar dapat menjangkau dan melayani orang-orang yang masih berada di luar jemaat Tuhan. Tidball menyatakan bahwa secara alkitabiah, pekerjaan penggembalaan mencakup tugas penginjilan yang berkesinambungan, karena tugas gembala bukan hanya melayani domba-domba yang ada sekarang, tetapi juga mereka yang masih perlu dicari dan dipersatukan dengannya (Tidball, 1995, p. 99). Domba-domba lain ini akan mendengar suara Yesus melalui pekabaran Injil oleh gereja dan disatukan dalam komunitas umat Allah, yaitu gereja.

Dengan demikian, dalam menjalankan tugas penggembalaan, seorang gembala jemaat tidak boleh melupakan Amanat Agung Yesus Kristus (Mat. 28:18-20), memperluas Kerajaan Allah. Selain harus fokus kepada jemaat yang digembalakannya, ia juga harus menaruh perhatian khusus kepada orang-orang yang 
belum percaya untuk memenangkan jiwa mereka dan menjadikannya umat Allah (1 Kor. 9:16). Penginjilan tidak boleh diabaikan oleh gembala jemaat dalam penyusunan program-program gereja, melainkan dijadikan salah satu prioritas sebab itulah tugas utama gereja. Gembala berkewajiban memperlengkapi setiap anggota jemaat untuk berperan sebagai pekabar-pekabar Injil yang efektif (Mrk. 1:17; Ef. 4:11-16).

\section{KESIMPULAN}

Kepemimpinan penggembalaan memiliki tugas dan tanggung jawab yang tidak mudah, terutama di dunia yang modern pada masa kini. Ada banyak tantangan baru, baik di dalam maupun di luar gereja yang siap menghadang dan akan menggagalkan kepemimpinan seorang gembala jemaat. Karena itu, kepemimpinan penggembalaan harus menyadari perlunya menerapkan prinsip-prinsip tertentu dalam pelaksanaan tugas dan tanggung jawabnya. Prinsip-prinsip yang tidak sama dengan prinsipprinsip kepemimpinan sekuler, sebab kepemimpinan penggembalaan jauh berbeda dari kepemimpinan sekuler. Prinsip-prinsip itu adalah prinsip-prinsip yang Alkitabiah atau bersumber dari firman Allah. Salah satunya adalah pengajaran Yesus melalui perumpamaan Gembala yang baik dalam Injil Yohanes 10:1-21. Ini adalah ajaran Yesus yang paling utama dan relevan dengan kepemimpinan penggembalaan. Berdasarkan pengajaran Yesus ini, dapatlah ditarik beberapa prinsip kepemimpinan penggembalaan yang perlu diimplementasikan pada kepemimpinan gereja. Beberapa prinsip itu adalah prinsip panggilan Allah, pemeliharaan, berpusat pada Yesus Kristus, pengorbanan, kesetaraan, dan perluasan kerajaan Allah.

Semua prinsip ini adalah sesuatu yang sangat mungkin untuk diterapkan atau dihidupi oleh seorang gembala dalam kepemimpinan gereja, jika ia ingin meneladani Yesus Kristus menjadi gembala yang baik. Tentu saja dengan tidak mengabaikan pertolongan dari Roh Kudus. Dengan pengimplementasian prinsip-prinsip ini dalam kepemimpinan penggembalaan, niscaya gembala sebagai pemimpin gereja dapat melaksanakan tugas penggembalaan dengan baik dan efektif. Gembala dapat membawa umat Allah kepada rencana dan tujuan Allah bagi mereka, yaitu mereka mempunyai hidup dan mempunyainya dalam segala kelimpahan.

\section{KEPUSTAKAAN}

Blackaby, Henry dan Richard. (2009). Kepemimpinan Rohani. Jakarta: Gospel.

Bons-Storm, M. (2008). Apakah Penggembalaan Itu? Jakarta: BPK Gunung Mulia.

Bryant, Beauford H., Mark S. Krause. (1998). John. Joplin, Mo.: College Press Pub. Co.

Carson, D. A. (1991). The Gospel According to John. Grand Rapids, Mi.: Wm. B.

Eerdmans Publishing Co.

Conner, Kevin J. (2004). Jemaat dalam Perjanjian Baru. Malang: Gandum Mas.

Fredrikson, Roger L., Lloyd J. Ogilvie. (1985). Seri The Preacher's Commentary, Volume

27: John. Nashville, Tennessee: Thomas Nelson Inc. 
Johnson, B. W. (1999). John: The New Testament Commentary, Vol. III. Oak Harbor, WA: Logos Research Systems, Inc.

Kruse, Colin G. (2003). John: An Introduction and Commentary. Nottingham, England: Inter-Varsity Press.

Lutzer, Erwin. (2010). Pastor to Pastor. Malang: Gandum Mas.

Michaels, J. Ramsey. (1989). New International Biblical Commentary: John. Peabody, MA: Hendrickson Publishers.

Morris, Leon. (1995). The Gospel According to John. Grand Rapids, MI: Wm. B. Eerdmans Publishing Co.

Prajogo, Natanael S. (2019). Implementasi Kepemimpinan Gembala yang Melayani

Berdasarkan 1 Petrus 5:2-10 di Kalangan Gembala Jemaat Gereja Bethel

Indonesia se-Jawa Tengah. Harvester: Jurnal Teologi dan kepemimpinan Kristen,

4(1), 1-21. http://e-journal.sttharvestsemarang.ac.id/index.php/harvester.

Rice, Howard. (2006). Manajemen Umat: Pendeta Sebagai Pengayom, Pemimpin, Pembina. Bandung: Kalam Hidup.

Ronda, Daniel. (2011). Leadership Wisdom: Antologi Hikmat Kepemimpinan. Bandung: Kalam Hidup.

Siahaya, Johannis. (2018). Kepemimpinan Kristen dalam Pluralitas Indonesia. Jurnal

Teruna Bhakti, 1(1), 1-16. http://stakterunabhakti.ac.id/e-

journal/index.php/teruna.

Sudgen, Howard F. dan Warren W. Wiersbe. (2009). Jawaban atas Masalah Penggembalaan. Malang: Gandum Mas.

Sudibyo, Irwanto. (2019). Pelayanan Kepemimpinan Penggembalaan Menurut Kisah

Para Rasul 20:17-38. Jurnal Teologi Gracia Deo, 2(1), 46-61. http://e-

journal.sttbaptisjkt.ac.id/index.php/graciadeo.

Sutanto, Hasan. (2007). Hermeneutik: Prinsip dan Metode Penafsiran Alkitab. Malang: Literatur SAAT.

Tenney, Merrill C. (1996). Injil Iman: Suatu Telaah Naskah Injil Yohanes Secara Analitis. Malang: Gandum Mas.

Tidball, Derek J. (1998). Teologi Penggembalaan. Malang: Gandum Mas.

Whitacre, Rodney A. (1999). John. Downers Grove, Ill.: InterVarsity Press.

Wijaya, Yahya. (2018). Kepemimpinan Yesus Sebagai Acuan Bagi Kepemimpinan

Gereja Masa Kini. Jurnal Jaffray, 16(2), 129-144.

http://ojs.sttjaffray.ac.id/index.php/JJV71/index.

Yuliastomo, Nicodemus dan Ivan Th. J. Weismann. (2010). Kepemimpinan Gembala:

Suatu Kajian Filosofis Tentang Proses Integrasi Kepemimpinan Rohani dan

Sekuler. Jurnal Jaffray, 8(1), 5-23. 